\title{
What Matters Most to Student Voters?: A Conjoint Analysis of Political Candidate Attributes
}

\author{
Ferdinand D. Anabo \\ Capiz State University, Capiz, Philippines
}

\section{Article history: \\ Submitted: 17 April 2021 \\ Revised: 29 May 2021 \\ Accepted: 15 June 2021}

\section{Keywords:}

Political science

Voting preference

Conjoint analysis

Student voters

Philippines

\begin{abstract}
Election is an essential instrument in the development of the country. Understanding key voting preferences could resolve issues facing the country through competent elected government officials. Election of future competent officials depends on the preference of the next generation of voters. This study aims to determine how political candidate attributes affect the voting preference of students and determine which of the political candidate attributes is the most important. The study used choice-based conjoint analysis, which simulates the real-world decision-making of choosing a candidate. Students were presented with different presidential candidates, each with a unique set of demographic and political attributes to choose from. Results suggest that student voters give importance to political attributes that reflect competencies such as profession, experience, accomplishments, and priorities. Political leaders must build their image through competence and good governance among student voters.
\end{abstract}

\subsection{Introduction}

The benefits of understanding the voting behavior and key decision criteria of voters cannot be belittled. The development of the country depends much on the programs and priorities of the elected leaders. Filipino voters are known to be inconsistent in their preferences and political beliefs, resulting in the election of incompetent government officials (Tandoc-Juan et al., 2019). The election process in the country has always been filled with fraud and violence (Murcia \& Bolo, 2017). The election of future competent leaders relies on the next generation of voters. First-time voters, such as most of the students, are in the process of developing their political self and identities (Børhaug, 2008). Politics and election is a multi-million business. This explains why only the rich, wealthy, and elite can participate in the game. Running for a position involves a lot of money. The risk is high as well as its reward. Understanding voters' preferences is advantageous to aspiring political leaders. They can build their strategies, programs, and priorities based on these preferences.

Determination of preferences is a key marketing research activity. According to Levy and Kotler (1969), marketing applies to persons, organizations, and ideas. Politics and elections are the marketing of people and policies. Shama (1975) used the term political marketing, referring to how political candidates and ideas are directed to voters to satisfy their political needs and thus gain their support. The promotion of products is similar to the promotion of political candidates. There is extensive use of media to inform, remind, and change attitudes and behavior (Shama, 1975). The similarity of consumer and voting behavior allows the application of selected marketing research tools to analyze voters' preferences.

Literature reveals interesting preferences of voters around the world. Some studies find physical attributes to be important in the success of an election. (Alsamydai \& Al Khasawneh, 2013; Hoegg \& Lewis, 2011; Klein \& Ahluwalia, 2005; Stanton, 2000; Todorov et al. 2005). Voters make trait inferences from facial features and are likely to vote for candidates that they perceive to be competent (Hall et al., 2009). Others find education and incumbency more important than appearance (Franchino \& Zucchini, 2013; Baker \& Myers, 2010). The character of the candidate seems to have mixed results in the literature. Bishin et al. (2008) observed no significant impact of candidates' character on voter's preference. Meanwhile, Alsamydai and Al Khasawneh (2013) find that character such as candidates' credibility is an important dimension to influence voters' selection decisions.

Studies on voter preferences were also conducted in the Philippines. One of the earliest studies was done by Ando (1969). He finds that language affiliation has the best explanatory power. The Institute of Political and Electoral Reform (IPER) conducted a much wider study in 1995 with an updated study in 2003. In the 1995 study, they found out that Filipinos choose candidates based on four factors: popularity; endorsement from social groups such as church and family; benefits that can be derived from the candidate; and lastly, party affiliation. A turn of findings happens in the 2003 
study. The benefit that can be derived from the candidate did become the most significant factor. This is followed by political machinery, popularity, and endorsement of social groups. In 2013, the Asian Institute of Management (AIM) Policy Center surveyed the educated youth. Results revealed that 90 percent chose candidates based on personalities, last names, and their television advertisements. AIM Policy Center economist David Yap II said, "When you take a close look at our results, it is not the ideology behind the candidates that motivates people to vote for them. It is the personality. It coheres with the notion that we have these personalistic politics." Popularity has become an important factor in the election. Political advertisements increase to improve the popularity of the candidates. Study on voters' preference remains an active area of research. The political arena of the country is comprised of diverse personalities. Ideology, physical, and competency attributes are not always the significant criteria in selecting a political candidate.

Most of the previous studies of voters' preferences used psychographic methods, which can be considered traditional. This method does not consider the trade-off between attributes. In aid to political marketing, conjoint analysis can also be used in determining what political attributes are significant to the voters for decision making. According to Yamamoto (2014), a professor of political science in Massachusetts Institute of Technology (MIT), "conjoint analysis is an ideal approach to determine what aspects of political candidates are important to the people". Respondents are presented with sets of candidates whose attributes (e.g., sex, party affiliation, accomplishment) are randomly combined. They will choose among the sets of candidates. The analysis will determine the weight of attributes (Hainmueller et al., 2013). The weight can be interpreted as utilities. Traditional survey experiments often create an artificial environment in which respondents are commonly given a single piece of information. The conjoint analysis provides various pieces of information jointly and lets respondents employ the information they find most relevant. This suggests that conjoint analysis may capture decision-making processes in information-rich environments more effectively than do traditional survey experiments (Alves \& Rossi, 1978).

This study explored the applicability of conjoint analysis in examining the voting preferences of students. Hence, this study can be considered exploratory in nature. Studies involving the use of conjoint analysis are very limited, especially in politics and elections. This study specifically sought to: (1) determine how political candidate attributes affect the voting preference of students; and (2) determine which of the political candidate attributes is the most important among students. Although this voting population may be considered a minority, they are the next voting generation. They are more informed than the general voting public. Students are exposed to education about the government processes that encourage political participation (Einfeld \& Collins, 2008; Finlay \& Flanagan, 2009; Kahne \& Middaugh, 2008). According to Colby (2007), college courses and cocurricular activities are positively related to political participation among students who have no political interest before. Students are also exposed to thoughtful discussion about political and current events (Pritzker, Springer \& McBride, 2015). This discussion may involve expressing sensible reasons for their preferences, exchanging information, listening to one another, and moving towards making a decision (Conover, Searing, \& Crewe, 2002). Deliberative classroom discussions enable students to understand, and tolerate diverse opinions, and reevaluate their responsibility as citizens and their participation in the community (Callan, 2004).

\subsection{Framework of the Study}

Conjoint analysis is based on the Theory of Random Utility (Ben-Akiva \& Lerman, 1985; Domencich \& McFadden, 1975). Utility is defined to be the total satisfaction derived from consuming a product. If political candidates are "products", our choice of candidates results in a certain level of utility or satisfaction. Voters will choose candidates whom they perceived to give them the highest utility. The Theory of Random Utility asserts that utility is derived from the consumption of the attribute of the product and not the product itself. For instance, in politics, the utility of the voters comes from the attributes of the political candidate, such as platforms, accomplishment, and profession.

Theory of Random Utility states that the consumer's utility can be presented in the form:

$$
U_{i}=V_{i}+e_{i}
$$

where $U_{i}$ is the total utility derived from choosing alternative $i, V_{i}$ is the systematic component determined by the attribute factors, and $e_{i}$ is the random error term. The systematic component takes the form: 


$$
V_{i}=a_{i}+B^{\prime} x_{i}
$$

where $a_{i}$ is the alternative specific constant of the ith alternative, $B^{\prime}$ is the vector of the parameters, and $x_{i}$ is the vector of the levels of the product attributes in the ith alternative.

According to equations 1 and 2, the utility of choosing a president can be expressed as a function of attributes. This study examined political and demographic attributes. Political attributes considered are the previous position held, political affiliation, character, leadership style, priorities, and the number of projects accomplished. Meanwhile, the demographic attributes examined are sex, age, educational attainment, experience, and profession. This paper sought to estimate the utility, which is the parameter vector $\beta$ associated with each category of the attributes.

\subsection{Methods}

\section{Participants of the conjoint experiment}

A randomly selected sample of 53 students participated in the two conjoint experiments. The participants were second-year and third-year students taking an undergraduate program in a state university. These groups were selected because the majority would be first-time voters. Moreover, this is the level where students have enough exposure to classroom exchange of information and deliberative discussions about politics and current affairs. Twenty-six percent of the participants were male, and $74 \%$ were female, with a mean age of 19 years old.

The limited number of participants is one of the shortcomings of the study. Most conjoint studies involved sample sizes of up to 200 (Zarco, 2014). However, exploratory studies do not need to have large samples (Zarco, 2014). A sample size between 50 to 70 is acceptable (Hair, 2010; Zarco, 2014). Orme (2010) stated that even a sample of 30 is acceptable for exploratory work. Another limitation of the study is that the sample came from students of the same college. The results should be interpreted cautiously and may not apply to the entire student population.

\section{The conjoint experiment procedure}

Two conjoint experiments were conducted, and both followed the same conjoint procedure. The first experiment involved choosing of hypothetical presidential candidates given their political attributes, while the second experiment involved choosing candidates given their demographic attributes. The conjoint procedure used in this study follows Ryan and Farrar (2000). This is a fivestep procedure that includes: a) identification of attributes, b) assignment of levels per attribute, c) yielding of the candidate profile, d) selection of the presentation medium and method, e) selection of the technique to be used in analyzing the data. The details of each step for this study are as follows:

Identification of attributes. According to Azarcon et al. (2014), there are different ways in determining the attribute to be considered in the conjoint analysis. This can be done through literature survey and focus group discussion. This study used both methods. Candidate attributes such as sex, age, character, education, political affiliation, priorities, and issues were found to be significant factors in electoral success among the literature reviewed (Alsmydai \& Al Khasawneh, 2013; Franchino \& Zucchini, 2013; Hoegg \& Lewis, 2011; Klein \& Ahluwalia, 2005; Lawson, Lenz, Baker, \& Myers, 2010; Murcia \& Bolo, 2017; Stanton, 2000; Todorov et al. 2005). A focus group discussion (FGD) was conducted among students in the school to enrich the identification of attributes. In particular, FGD was used to identify important political attributes. Ten students participated in the FGD. The participants were asked, "What is your criteria in voting for a president?", This question solicits the important political attributes for students. Common recurring answers observed in the discussions were: priorities, accomplishments, performance, leadership style, experience from the previous position, reputation, and political affiliation. Some participants also answered competence, ability, and not corrupt. From these answers, eight political attributes were deduced. However, conjoint analysis is only effective for up to 6 attributes. The 6 attributes used were previous position held, political affiliation, character reputation, leadership style, and the number of projects/programs established (Table 1). The conduct of FGD satisfies principles of communicable and actionable measures among the attributes (Hair, 2010). Communicable means that the attributes (demographic and political) are understood by the participants. 
Table 1. Political attributes and their categories

\begin{tabular}{ll}
\hline \multicolumn{1}{c}{ Political attributes } & \multicolumn{1}{c}{ Categories/level of the attributes } \\
\hline Previous position held & $\begin{array}{l}\text { Governor } \\
\text { Senator }\end{array}$ \\
\hline Political affiliation & $\begin{array}{l}\text { With political party } \\
\text { Independent }\end{array}$ \\
\hline Character reputation & $\begin{array}{l}\text { Have not been accused of corruption. } \\
\text { Have been accused of corruption }\end{array}$ \\
\hline Leadership style & Authoritative \\
\hline \multirow{3}{*}{ Democratic } \\
\hline $\begin{array}{l}\text { Number of projects/programs } \\
\text { established during the previ- } \\
\text { ous positions implemented }\end{array}$ & $\begin{array}{l}\text { Poverty alleviation } \\
\text { Economic growth } \\
\text { Improved government progrograms implemented }\end{array}$ \\
\hline
\end{tabular}

Assigning of Categories or Levels per Attribute. The categories or levels per attribute were also determined during the FGD. The second question asked to the participants was, "How can you say that the presidentiable is competent?". This question solicits more specific criteria about political attributes. The recurring answers among participants were many projects implemented, successful projects implemented, not accused of corruption, not a dictator, and programs that can alleviate poverty and economic growth. These answers were grouped according to what attributes they belong to and modified to suit the conjoint analysis. For example, the answer "many projects implemented" was changed to the number of programs and projects implemented. This is more specific than using the term "many" or "more" and, in some cases, "good" and "better". These words are vague, and voters may have different perceptions of these terms. The attribute "number of projects" has categories such as 2 projects, 6 projects, and 12 projects (Table 1 ). These categories are easy to understand. Objectively, a presidentiable with 12 projects implemented has more accomplishments than those with 2 projects. The same modifications were also done among other attributes and categories. The categories were rechecked and examined to avoid the existence of impossible combinations. For example, a candidate cannot be 30 years old yet have 15 years of experience in politics. The candidate could have started his political career at the age of 15 years which is not allowed. Table 1 and 2 shows the attributes and categories used in generating the profile of hypothetical presidential candidates.

Table 2. Demographic attributes and their categories

\begin{tabular}{ll}
\hline \multicolumn{1}{c}{ Demographic attributes } & \multicolumn{1}{c}{ Categories/level of the attributes } \\
\hline \multirow{2}{*}{ Sex } & Male \\
& Female \\
\hline \multirow{2}{*}{ Age } & 45 \\
& 60 \\
\hline \multirow{2}{*}{ Educational attainment } & Bachelors \\
& Masters \\
\multirow{2}{*}{ Experience } & 2 years \\
& 6 years \\
\multirow{2}{*}{ Profession before engaging in } & 12 years \\
politics & Lawyer \\
& Military men \\
\hline
\end{tabular}


Yielding of candidate profile. The categories/levels for each attribute were combined to form several unique hypothetical presidential candidate profiles. A total of $144(2 \times 2 \times 2 \times 2 \times 3 \times 3)$ candidate profiles for the first conjoint experiment can be formulated based on the 6 political attributes. Seventy two $(2 \times 2 \times 2 \times 3 \times 3)$ candidate profiles can be formulated in the second conjoint experiment based on the 5 demographic attributes. These numbers of profiles were reduced using fractional factorial design (Hair, 2010). It is a method of selecting a sample of possible profiles that do not correlate with levels across attributes. The number of levels for each attribute is balanced. The SPSS orthogonal command was used in generating the number of profiles for the two conjoint experiments. SPSS generated 20 candidate profiles for each experiment (Table 3 and 4).

Table 3. Profile of presidential candidates using political attributes

\begin{tabular}{|c|c|c|c|c|c|c|}
\hline Profile & $\begin{array}{l}\text { Previous } \\
\text { Position } \\
\text { Held }\end{array}$ & $\begin{array}{l}\text { Political } \\
\text { Affiliation }\end{array}$ & Character Reputation & $\begin{array}{l}\text { Leadership } \\
\text { style }\end{array}$ & Priorities & $\begin{array}{c}\text { Number of } \\
\text { Projects }\end{array}$ \\
\hline 1 & Governor & Independent & $\begin{array}{l}\text { Have not been accused } \\
\text { of corruption }\end{array}$ & Democratic & $\begin{array}{l}\text { Economic } \\
\text { Growth }\end{array}$ & $\begin{array}{l}12 \text { Projects } \\
\text { Established }\end{array}$ \\
\hline 2 & Senator & $\begin{array}{l}\text { With Political } \\
\text { Party }\end{array}$ & $\begin{array}{l}\text { Have not been accused } \\
\text { of corruption }\end{array}$ & Authoritative & $\begin{array}{l}\text { Poverty } \\
\text { Alleviation }\end{array}$ & $\begin{array}{l}12 \text { Projects } \\
\text { Established }\end{array}$ \\
\hline 3 & Senator & Independent & $\begin{array}{c}\text { Have not been accused } \\
\text { of corruption }\end{array}$ & Authoritative & $\begin{array}{l}\text { Poverty } \\
\text { Alleviation }\end{array}$ & $\begin{array}{l}12 \text { Projects } \\
\text { Established }\end{array}$ \\
\hline 4 & Senator & $\begin{array}{l}\text { With Political } \\
\text { Party }\end{array}$ & $\begin{array}{c}\text { Have been accused of } \\
\text { corruption }\end{array}$ & Democratic & $\begin{array}{l}\text { Economic } \\
\text { Growth }\end{array}$ & $\begin{array}{l}6 \text { Projects } \\
\text { Established }\end{array}$ \\
\hline 5 & Governor & Independent & $\begin{array}{c}\text { Have been accused of } \\
\text { corruption }\end{array}$ & Democratic & $\begin{array}{l}\text { Improved } \\
\text { Government } \\
\text { Services }\end{array}$ & $\begin{array}{l}2 \text { Projects } \\
\text { Established }\end{array}$ \\
\hline 6 & Senator & Independent & $\begin{array}{l}\text { Have been accused of } \\
\text { corruption }\end{array}$ & Democratic & $\begin{array}{l}\text { Poverty } \\
\text { Alleviation }\end{array}$ & $\begin{array}{l}12 \text { Projects } \\
\text { Established }\end{array}$ \\
\hline 7 & Senator & $\begin{array}{l}\text { With Political } \\
\text { Party }\end{array}$ & $\begin{array}{l}\text { Have not been accused } \\
\text { of corruption }\end{array}$ & Democratic & $\begin{array}{l}\text { Improved } \\
\text { Government } \\
\text { Services }\end{array}$ & $\begin{array}{l}12 \text { Projects } \\
\text { Established }\end{array}$ \\
\hline 8 & Governor & $\begin{array}{l}\text { With Political } \\
\text { Party }\end{array}$ & $\begin{array}{c}\text { Have not been accused } \\
\text { of corruption }\end{array}$ & Democratic & $\begin{array}{c}\text { Poverty } \\
\text { Alleviation }\end{array}$ & $\begin{array}{c}2 \text { Projects } \\
\text { Established }\end{array}$ \\
\hline 9 & Governor & Independent & $\begin{array}{l}\text { Have not been accused } \\
\text { of corruption }\end{array}$ & Authoritative & $\begin{array}{l}\text { Economic } \\
\text { Growth }\end{array}$ & $\begin{array}{l}12 \text { Projects } \\
\text { Established }\end{array}$ \\
\hline 10 & Senator & $\begin{array}{l}\text { With Political } \\
\text { Party }\end{array}$ & $\begin{array}{c}\text { Have been accused of } \\
\text { corruption }\end{array}$ & Authoritative & $\begin{array}{l}\text { Economic } \\
\text { Growth }\end{array}$ & $\begin{array}{l}2 \text { Projects } \\
\text { Established }\end{array}$ \\
\hline 11 & Governor & Independent & $\begin{array}{c}\text { Have been accused of } \\
\text { corruption }\end{array}$ & Democratic & $\begin{array}{l}\text { Poverty } \\
\text { Alleviation }\end{array}$ & $\begin{array}{l}12 \text { Projects } \\
\text { Established }\end{array}$ \\
\hline 12 & Governor & Independent & $\begin{array}{l}\text { Have been accused of } \\
\text { corruption }\end{array}$ & Authoritative & $\begin{array}{c}\text { Poverty } \\
\text { Alleviation }\end{array}$ & $\begin{array}{l}6 \text { Projects } \\
\text { Established }\end{array}$ \\
\hline 13 & Governor & $\begin{array}{l}\text { With Political } \\
\text { Party }\end{array}$ & $\begin{array}{l}\text { Have not been accused } \\
\text { of corruption }\end{array}$ & Authoritative & $\begin{array}{l}\text { Improved } \\
\text { Government } \\
\text { Services }\end{array}$ & $\begin{array}{l}6 \text { Projects } \\
\text { Established }\end{array}$ \\
\hline 14 & Governor & $\begin{array}{l}\text { With Political } \\
\text { Party }\end{array}$ & $\begin{array}{c}\text { Have been accused of } \\
\text { corruption }\end{array}$ & Authoritative & $\begin{array}{l}\text { Economic } \\
\text { Growth }\end{array}$ & $\begin{array}{l}12 \text { Projects } \\
\text { Established }\end{array}$ \\
\hline 15 & Senator & Independent & $\begin{array}{l}\text { Have not been accused } \\
\text { of corruption }\end{array}$ & Democratic & $\begin{array}{l}\text { Economic } \\
\text { Growth }\end{array}$ & $\begin{array}{l}6 \text { Projects } \\
\text { Established }\end{array}$ \\
\hline 16 & Senator & Independent & $\begin{array}{l}\text { Have not been accused } \\
\text { of corruption }\end{array}$ & Authoritative & $\begin{array}{l}\text { Economic } \\
\text { Growth }\end{array}$ & $\begin{array}{l}2 \text { Projects } \\
\text { Established }\end{array}$ \\
\hline 17 & Governor & $\begin{array}{l}\text { With Political } \\
\text { Party }\end{array}$ & $\begin{array}{c}\text { Have been accused of } \\
\text { corruption }\end{array}$ & Democratic & $\begin{array}{l}\text { Economic } \\
\text { Growth }\end{array}$ & $\begin{array}{l}12 \text { Projects } \\
\text { Established }\end{array}$ \\
\hline 18 & Governor & Independent & $\begin{array}{c}\text { Have been accused of } \\
\text { corruption }\end{array}$ & Authoritative & $\begin{array}{c}\text { Economic } \\
\text { Growth }\end{array}$ & $\begin{array}{c}2 \text { Projects } \\
\text { Established }\end{array}$ \\
\hline 19 & Senator & Independent & $\begin{array}{c}\text { Have been accused of } \\
\text { corruption }\end{array}$ & Authoritative & $\begin{array}{l}\text { Improved } \\
\text { Government } \\
\text { Services }\end{array}$ & $\begin{array}{l}12 \text { Projects } \\
\text { Established }\end{array}$ \\
\hline 20 & Senator & Independent & $\begin{array}{c}\text { Have been accused of } \\
\text { corruption }\end{array}$ & Authoritative & $\begin{array}{l}\text { Improved } \\
\text { Government } \\
\text { Services }\end{array}$ & $\begin{array}{l}2 \text { Projects } \\
\text { Established }\end{array}$ \\
\hline
\end{tabular}


Table 4. Profile of presidential candidates using demographic attributes

\begin{tabular}{|c|c|c|c|c|c|}
\hline Profile & Sex & Age & $\begin{array}{l}\text { Educational } \\
\text { Attainment }\end{array}$ & Experience & Profession \\
\hline 1 & Male & 60 & Masters & 2 years & Lawyer \\
\hline 2 & Male & 45 & Bachelors & 2 years & Celebrity \\
\hline 3 & Female & 45 & Bachelors & 6 years & Lawyer \\
\hline 4 & Female & 45 & Masters & 6 years & Military \\
\hline 5 & Female & 45 & Bachelors & 2 years & Celebrity \\
\hline 6 & Male & 45 & Bachelors & 12 years & Celebrity \\
\hline 7 & Female & 60 & Bachelors & 2 years & Lawyer \\
\hline 8 & Female & 45 & Masters & 2 years & Lawyer \\
\hline 9 & Female & 60 & Bachelors & 12 years & Celebrity \\
\hline 10 & Female & 60 & Bachelors & 6 years & Lawyer \\
\hline 11 & Male & 60 & Masters & 6 years & Celebrity \\
\hline 12 & Male & 60 & Bachelors & 6 years & Lawyer \\
\hline 13 & Female & 60 & Masters & 2 years & Military \\
\hline 14 & Male & 60 & Bachelors & 2 years & Military \\
\hline 15 & Male & 45 & Masters & 12 years & Lawyer \\
\hline 16 & Male & 45 & Bachelors & 12 years & Military \\
\hline 17 & Female & 60 & Masters & 12 years & Lawyer \\
\hline 18 & Male & 45 & Masters & 2 years & Celebrity \\
\hline 19 & Male & 45 & Bachelors & 2 years & Lawyer \\
\hline 20 & Female & 60 & Masters & 2 years & Lawyer \\
\hline
\end{tabular}

Selection of the presentation method. The full-profile presentation method was used in the study. It is the most popular method because of its perceived realism and its ability to reduce the number of comparisons through fractional factorial design (Hair, 2010). The participants were presented with candidates with a complete set of unique profiles from the identified attributes and levels. The participants were asked to choose one among the four hypothetical candidates. This is known as the choice-based conjoint method. The 20 full profiles of the hypothetical candidates were divided into five-choice sets, with each set having four candidates with unique profiles and an option of choosing "none" if the respondent's preference is not among the choices in the set. Table 5 and 6 shows an example of a choice set in a choice-based conjoint task for the political and demographic attribute

The conjoint experiment was done using a questionnaire. The questionnaires were given to the participants and were retrieved after two days. This is to give time for the participants to choose properly and to increase the validity of the response.

Selection of the technique used to analyze the data. The hallmark of conjoint analysis is the generation of utility for each level/category of the attribute and the overall importance score of each attribute. The utility is estimated using conditional logit regression. The utility presents the preference for the levels/categories in each attribute. XLSTAT was the software used to generate the utility and the importance score. 
Table 5. Sample conjoint task on political attribute of the candidate

\begin{tabular}{|c|c|c|c|c|c|}
\hline Attributes & President 13 & President 14 & President 15 & President 16 & None \\
\hline $\begin{array}{c}\text { Previous } \\
\text { Position Held }\end{array}$ & Governor & Governor & Senator & Senator & \multirow{6}{*}{$\begin{array}{l}\text { If these were } \\
\text { the only } \\
\text { presidentiables, } \\
\text { I would not vote } \\
\text { for any one of } \\
\text { them. }\end{array}$} \\
\hline $\begin{array}{c}\text { Political } \\
\text { Affiliation }\end{array}$ & $\begin{array}{l}\text { With Political } \\
\text { Party }\end{array}$ & $\begin{array}{l}\text { With Political } \\
\text { Party }\end{array}$ & Independent & Independent & \\
\hline $\begin{array}{l}\text { Character } \\
\text { Reputation }\end{array}$ & $\begin{array}{l}\text { Have not been } \\
\text { accused of } \\
\text { corruption }\end{array}$ & $\begin{array}{l}\text { Have been } \\
\text { accused of } \\
\text { corruption }\end{array}$ & $\begin{array}{c}\text { Have not been } \\
\text { accused of } \\
\text { corruption }\end{array}$ & $\begin{array}{c}\text { Have not been } \\
\text { accused of } \\
\text { corruption }\end{array}$ & \\
\hline $\begin{array}{l}\text { Leadership } \\
\text { Style }\end{array}$ & Authoritative & Authoritative & Democratic & Authoritative & \\
\hline Priorities & $\begin{array}{l}\text { Improved } \\
\text { Government } \\
\text { Services }\end{array}$ & $\begin{array}{l}\text { Economic } \\
\text { Growth }\end{array}$ & $\begin{array}{l}\text { Economic } \\
\text { Growth }\end{array}$ & $\begin{array}{l}\text { Economic } \\
\text { Growth }\end{array}$ & \\
\hline $\begin{array}{l}\text { Number } \\
\text { of Projects } \\
\text { Established }\end{array}$ & $\begin{array}{l}6 \text { Projects } \\
\text { Established }\end{array}$ & $\begin{array}{l}12 \text { Projects } \\
\text { Established }\end{array}$ & $\begin{array}{l}6 \text { Projects } \\
\text { Established }\end{array}$ & $\begin{array}{l}2 \text { Projects } \\
\text { Established }\end{array}$ & \\
\hline $\begin{array}{l}\text { Kindly check } \\
\text { here }\end{array}$ & & & & & \\
\hline
\end{tabular}

Table 6. Sample conjoint task on demographic attribute of the candidate

\begin{tabular}{|c|c|c|c|c|c|}
\hline Attributes & President 1 & President 2 & President 3 & President 4 & None \\
\hline Sex & Male & Male & Female & Female & \multirow{5}{*}{$\begin{array}{l}\text { If these were } \\
\text { the only } \\
\text { presidentiables, } \\
\text { I would not vote } \\
\text { for any one of } \\
\text { them. }\end{array}$} \\
\hline Age & 60 & 45 & 45 & 45 & \\
\hline $\begin{array}{l}\text { Educational } \\
\text { Attainment }\end{array}$ & Masters & Bachelors & Bachelors & Masters & \\
\hline $\begin{array}{l}\text { Length of } \\
\text { Experience in } \\
\text { Government } \\
\text { Service }\end{array}$ & 2 years & 2 years & 6 years & 6 years & \\
\hline Profession & Lawyer & Male & Female & Female & \\
\hline $\begin{array}{l}\text { Kindly check } \\
\text { here }\end{array}$ & & & & & \\
\hline
\end{tabular}

\subsection{Results and Discussion}

\section{Conjoint analysis of political attributes}

The computed utility score for the political attributes is shown in Table 7. In terms of the previous position held, the governor has a positive utility $(0.021)$ while the senator has a negative utility $(-0.021)$. This implies that student voters prefer presidential candidates who have served as governor compared to those who have served as senators. Independent presidential candidates yielded a positive utility (0.139), while those candidates with a political party yielded negative utility $(-0.139)$. This means that student voters prefer candidates who are not identified with any political party than those who belong in a political party. Student voters prefer those presidential candidates who have not been accused of corruption with a positive utility of 0.232 . Student voters assess the integrity and morality of the candidates. 
Students also prefer candidates who are democratic in their leadership style with a positive utility of 0.208 than those who are authoritative (-0.208). A democratic leader has a strong appeal to the students because this group of voters wants to participate in the governance of the country. Students wanted their voices to be heard. It can always be observed that the youth are always in the frontline of protest whenever their cause is perceived to be unheard (Valte, 1987). Perhaps the youth is aware of the grim regime of Martial Law, which is strongly associated with authoritarianism.

Table 7. Utility score of political attributes factors

\begin{tabular}{lcc}
\hline Political Attribute & Utilities & Standard deviation \\
\hline Previous Position Held & & \\
$\quad$ Governor & 0.021 & 0.094 \\
$\quad-0.021$ & 0.094 \\
\hline Senator & & \\
\hline Political Affiliation & 0.139 & 0.086 \\
$\quad$ Independent & -0.139 & 0.086 \\
$\quad$ With Political Party & & \\
\hline Character Reputation & -0.232 & 0.095 \\
$\quad$ Have been accused of corruption & 0.232 & 0.095 \\
$\quad$ Have not been accused of corruption & & \\
\hline Leadership Style & -0.208 & 0.102 \\
$\quad$ Authoritative & 0.208 & 0.102 \\
$\quad$ Democratic & & \\
\hline Priorities & & 0.141 \\
$\quad$ Economic Growth & 0.684 & 0.158 \\
Improved Government Services & -0.082 & 0.154 \\
$\quad$ Poverty Alleviation & -0.603 & 0.179 \\
\hline Number of Projects Established & & \\
2 Projects Established & -0.688 & 0.124 \\
6 Projects Established & 0.007 & \\
12 Projects Established & 0.682 & \\
\hline
\end{tabular}

Economic growth was preferred with a positive utility (0.684) than improved government services and poverty alleviation. Student voters find economic growth to be more important than the rest of the other priorities. Economic growth is foreseen to affect the students in the area of employment. A growing economy is perceived to create more jobs. In terms of the number of projects established, student voters preferred candidates with 12 projects established in their previous position with the highest positive utility of 0.682 . Projects established may reflect the accomplishment of the presidential candidate. Students prefer candidates with output.

Taking into account all the factors with the highest positive utilities in each political attribute, the most preferred presidential candidate possesses the following characteristics: the previous position held is governor; independent; have not been accused of corruption; democratic leadership style; economic growth is the priority; and have established 12 projects. This result supports the study of Murcia and Bolo (2017) who finds that millennial voters prefer presidentiable who is an economist, liberal thinker, and prioritize economic growth.

Table 8 shows the relative importance of each attribute. The result revealed that the number of projects established has the highest importance score of $33.38 \%$, followed by priority $(33.38 \%)$ and 
character reputation (12.018\%). The least important political attribute is the previous position held with an importance score of $1.066 \%$. These importance score imply that students give more weight to the number of projects established by the candidates when deciding to vote. Accomplishment reveals the capacity of leaders to be effective and efficient in achieving the goals for their constituents. Student voters are also concerned with the priorities of the candidates. Leaders with clear priorities indicate the existence of a vision and direction. This also suggests whether or not the candidates' plans are relevant to the voters. Leaders with character are trustworthy and free of corrupt practices.

Table 8. Importance score of political attributes

\begin{tabular}{llc}
\hline Political Attributes & Importance Score & Rank \\
\hline Number of Projects & 35.537 & 1 \\
Priorities & 33.38 & 2 \\
Character Reputation & 12.018 & 3 \\
Leadership style & 10.805 & 4 \\
Political Affiliation & 7.195 & 5 \\
Previous Position Held & 1.066 & 6 \\
\hline
\end{tabular}

\section{Conjoint analysis of demographic attributes}

Table 9 shows the utility score of the demographic attributes. The result revealed that student voters prefer male candidates with a positive utility score of 0.109 than female candidates $(-0.019)$. While our political system recognizes the participation of women in politics, the preference for males is still dominant. The majority of the positions in the government are occupied by males (Philippine Commission on Women, n.d.). Students also prefer candidates aging 45 years old with a utility score of 0.232 than those candidates with age 60 years old. Students tend to identify themselves with the young candidates. According to Webster and Pierce (2019), age act as a voting heuristics or informational shortcut, and the voting population tend to vote for those who are closest to them in age.

Presidential candidates with master's degrees (0.077) are more preferred than those candidates with bachelor's degrees. The educational qualification reflects the intellectual competence of the candidate. Students are an academically inclined group of individuals as they are expected to study and perform well in class. Students give high regard to individuals with higher academic accomplishments. In terms of experience, student voters prefer candidates with 12 years of experience $(0.915)$ to those candidates with 6 years and 2 years of experience. Students perceived that a candidate is capable of leading if he has a considerable amount of experience. By profession, lawyers were preferred more by student voters $(0.944)$ than military $(0.253)$ and showbiz personnel $(-1.197)$. The president is an executive office whose main function is the execution of policies and programs. Students are aware of the duties and responsibilities of the president and find that a candidate who is a lawyer by profession is more suited to lead than military men and showbiz personalities.

Based on the factors with the highest positive utilities, the most preferred presidential candidate is someone who is: male; 45 years old; has a master's degree; has 12 years of experience; and a lawyer by profession.

Table 10 shows the importance score of the demographic attributes of the candidates. The result shows that the most important demographic attribute is the candidate's profession (48.886\%) and followed by their experience (32.007\%). The least important attribute is sex (4.979\%). Candidates who are lawyers and have long experience are perceived to be more competent. Presidential candidates must prove that they have substantial knowledge and understanding of the law and constitution. Almost every action of the president must be in accordance with the constitution. Student voters do not prefer the candidate who is a novice. Experience may speak how well the candidate is prepared to take the challenge. Hence, candidates should emphasize their political experience to the student voters. Although the study used the length of time in experience, one may also present the depth of his experience to be more appealing to the students. 
Table 9. Utility score of demographic attribute factors

\begin{tabular}{|c|c|c|}
\hline Demographic Attribute Factors & Utilities & Standard deviation \\
\hline \multicolumn{3}{|l|}{ Sex } \\
\hline Female & -0.109 & 0.086 \\
\hline Male & 0.109 & 0.086 \\
\hline \multicolumn{3}{|l|}{ Age } \\
\hline 45 years old & 0.232 & 0.099 \\
\hline 60 years old & -0.232 & 0.099 \\
\hline \multicolumn{3}{|l|}{ Educational Attainment of Candidates } \\
\hline Bachelor's Degree & -0.077 & 0.079 \\
\hline Master's Degree & 0.077 & 0.079 \\
\hline \multicolumn{3}{|l|}{ Experience of Candidates } \\
\hline 2 years & -0.487 & 0.126 \\
\hline 6 years & -0.428 & 0.207 \\
\hline 12 years & 0.915 & 0.168 \\
\hline \multicolumn{3}{|l|}{ Profession of Candidates } \\
\hline Lawyer & 0.944 & 0.118 \\
\hline Military & 0.253 & 0.191 \\
\hline Showbiz personnel & -1.197 & 0.215 \\
\hline
\end{tabular}

Table 10. Importance score of demographic attributes

\begin{tabular}{lll}
\hline Demographic Attributes & Importance Score & Rank \\
Profession & 48.886 & 1 \\
Experience & 32.007 & 2 \\
Age & 10.6 & 3 \\
Sex & 4.979 & 4 \\
Educational Attainment & 3.528 & 5 \\
\hline
\end{tabular}

\subsection{Conclusion}

This paper explored the applicability of conjoint analysis in the study of the voting preference of students. This study specifically sought to: (1) determine how political candidate attributes affect the voting preference of students; and (2) determine which of the political candidate attributes is the most important for students. For political attributes, the result revealed that students prefer candidates whose previous position is a governor; independent; have not been accused of corruption; democratic; economic growth is the priority and has established 12 projects. The most important political attribute is the number of projects established. In terms of demographic attributes, students prefer a presidential candidate who is male, young, has a master's degree, has long experience, and a lawyer by profession. The most important demographic attribute for the student is profession and experience.

The results of the study bear connotations in the area of public administration and governance. The study showed that students base their decisions on competency attributes. Existing leaders aspiring for a higher position must build their image on the aspect of accomplishment, platforms, priorities, character, profession, and experience to gain the support of student voters. Amidst the 
country's violent and fraudulent electoral system, students remain to be sound in their preference for political leaders (Murcia \& Bolo, 2017).

The major shortcoming of the study is the limited number of research participants. A similar study can be conducted involving a larger sample size, probably not only student voters but also voters from other sectors. Another limitation of the study is that the sample came from students from one college. The results may not apply to the entire student population.

The choice-based conjoint study applies to up to six attributes. This is the reason why the conjoint experiment was divided into two experiments to accommodate this condition. For future research studies, one conjoint experiment can combine the demographic and political attributes to test whether one of the two attributes is more important. Traditional conjoint analysis can also be tested using ranking and ratings. Researchers can also examine other political and demographic attributes not included in the study.

\section{REFERENCES}

Alsamydai, M. J., \& Al Khasawneh, M.H. (2013). Basic Criteria for the Success of the Electoral Candidates and their Influence on Voters' Selection Decision. Advances in Management \& Applied Economics, vol. 3, 105-127

Alves, W. M., \& Rossi, P. H. (1978). Who should get what? Fairness judgments of the distribution of earnings. American Journal of Sociology. 84, 541-564.

Ando, H. (1969).A Study of Voting Patterns in the Philippine Presidential and Senatorial Elections, 1946-1965. Midwest Journal of Political Science 13(4), 567-586

Asian Institute of Management (AIM). (2013). Educated youth still vote based on personalities, adverts. GMA News

Azarcon, D. E. Jr., Gallardo, C.D., Anacin, C.J., \& Velasco, E. (2014). Attrition and Retention in Higher Education Institution: A Conjoint Analysis of Consumer Behavior in Higher Education. Asia Pacific Journal of Education, Arts and Sciences 1(5),

Ben-Akiva, M., \& Lerman, S. (1985). Discrete choice analysis: Theory and application to travel demand. Cambridge, MA: MIT Press.

Bishin, B.G., Stevens, D., \& Wilson, C. (2008).Character Counts? Honesty and Fairness in the Election 2000. Public Opinion Quarterly Oxford Journals Vol. 70, Issue 2. Accessed July 6, 2015.http://poq.oxfordjournals.org/ content/70/2/235.abstract.

Børhaug, K. (2008). Educating voters: Political education in Norwegian upper secondary schools. Journal of Curriculum Studies, 40(5), 579-600.

Callan, E. (2004). Citizenship and education. Annual Review of Political Science 7, 71-90.

Colby, A., Beaumont, E., Ehrlich, T., \& Corngold, J. (2007). Educating for democracy. Stanford, CA: Carnegie Foundation for the Advancement of Teaching.

Conover, P.J., Searing, D., \& Crewe, I.M. (2002). The deliberative potential of political discussion. British Journal of Political Science 32(1), 21-62.

Domencich, T., \& McFadden, D. L. (1975). Urban travel demand: A behavioral analysis. New York: American Elsevier Publishing Company.

Einfeld, A., \& Collins, D. (2008). The relationships between service-learning, social justice, multicultural competence, and civic engagement. Journal of College Student Development 49(2), 95-109.

Finlay, A., \& Flanagan, C. (2009). Making educational progress: links to civic engagement during the transition to adulthood. Retrieved from http:// www.civicyouth.org/PopUps/WorkingPapers/ WP_67_Finlay_Flanagan. pdf.

Franchino, F., \& Zucchini, F. (2013).Conjoint analysis of voting behavior: A stated preference experiment employing valence and ideology attributes of candidates. Accessed June 14, 2015.https://www.researchgate. net/publication/256049261_Conjoint_Analysis_of_Voting_Behavior_A_Stated_Preference_Experiment_ Employing_Valence_and_Ideology_Attributes_of_Candidates

Hainmueller, J., Hopkins, D., \& Yamamoto, T. (2014). Causal Inference in Conjoint Analysis: Understanding Multidimensional Choices via Stated Preference Experiments. Political Analysis, 22(1), 1-30. doi:10.1093/ pan/mpt024

Hair, J. F. (2010). Multivariate data analysis 7th Edition. Pearson Prentice Hall

Hall, C., Goren, A., Chaiken, S., \& Todorov, A. (2009). Shallow cues with deep effects: Trait judgments from faces and voting decisions. In E. Borgida, J. L. Sullivan, \& C. M. Federico (Eds.), The political psychology of democratic citizenship. Oxford University Press.

Hoegg, J., \& Lewis MV.(2011). The Impact of Candidate Appearance and Advertising Strategies on Election Results. Journal of Marketing Research. 48(5):895-909. doi:10.1509/jmkr.48.5.895

Institute for Political and Electoral Reform (IPER) (2003). Restudying the Filipino Voters Today. Accessed June 13, 2015. iper.org.ph/documentation/Chapter\%2001-09.pdf

Kahne, J., \& Middaugh, E. (2008). High-quality civic education: what is it, and who gets it? Social Education 72(January-February), 34-39. 
Klein, J.G., \& Ahluwalia, R. (2005), "Negativity in the Evaluation of Political Candidates," in NA - Advances in Consumer Research Volume 32, eds. Geeta Menon and Akshay R. Rao, Duluth, MN: Association for Consumer Research, Pages: 21-22. http://www.acrwebsite.org/volumes/9016/volumes/v32/NA-32

Lawson, C., Lenz, G.S., Baker, A. \& Myers, M. (2010). Looking Like a Winner: Candidate Appearance and Electoral Success in New Democracies. World Politics, Volume 62, Number 4, October 2010, pp. 561-593. Cambridge University Press

Levy, S., \& Kotler, P. (1969). Broadening the Concept of Marketing. Journal of Marketing. 33, 10-15

Murcia, J.V. B., \& Bolo, R. L. T. (2017). Millennial Voters' Preference for the 2016 Philippine Presidential Elections : A Millennial Voter s' Preference for the 2016 Philippine Presidential Elections : A Simulation Using Conjoint Analysis, (September 2018). https://doi.org/10.2139/ssrn.2983023

Orme, B. (2010). Getting started with conjoint analysis: Strategies for product design and pricing research. Madison, Wisconsin: Research Publishers LLC.

Pritzker, S., Springer, M., \& McBride, A. M. (2015). Learning to Vote : Informing Political Participation among College Students, 8(1)

Ryan, M., \& Farrar, S. (2000). Using conjoint analysis to elicit preferences for health care. BMJ (Clinical research ed.), 320(7248), 1530-1533. https://doi.org/10.1136/bmj.320.7248.1530

Philippine Commission on Women. (n.d.). https://pcw.gov.ph/womens-political-participation-and representation/ Women comprisehal of the, fifth of government elected positions in the 2019 national and, of the candidates were female.

Shama, A. (1975). An Analysis of Political Marketing in SV - Broadening the Concept of Consumer Behavior, eds. Gerald Zaltman and Brian Sternthal, Cincinnati, OH: Association for Consumer Research, Pages: 106-116.

Stanton, F. (2000). The First Debate over Presidential Debates. Newsweek, 136(13), 11.

Tandoc-Juan, M. V., Juan, M. J., \& Atianzar, M. (2019). Political candidates' profile through the lens of student voters. Educational Research International, 8(4) (November), 42-51.

Todorov, A., Mandisodza, A. N., Goren, A., \& Hall, C. C. (2005). Inferences of Competence from Faces Predict Election Outcomes. Science, 308(5728), 1623-1626.

Valte, Maricris. (1987). The Philippine Student Movement: Prospects for a Dynamic Student Politics. Kasarinlan: Philippine Quarterly of Third World Studies. 2.

Webster, S.W., \& Pierce, A.W. (2019), Older, Younger, or More Similar? The Use of Age as a Voting Heuristic*. Social Science Quarterly, 100: 635-652. https://doi.org/10.1111/ssqu.12604

Zarco, T. (2014). The Influence of Materialism on Consumer Preferences: A Conjoint Analysis Approach. Philippine Management Review Vol. 21, 39-52

\section{Correspondence:}

FERDINAND D. ANABO

drefboana@gmail.com

https://orcid.org/0000-0001-9176-840X 